\title{
Perbandingan dan Sintesa Karakteristik Perilaku Perjalanan Penumpang KA Komuter SULAM dan KA Komuter SUPOR
}

\author{
Comparison and Synthese of Passenger Travel Behavior \\ Characteristics of SULAM and SUPOR Commuter Trains
}

\author{
Anita Susanti $^{1,2, a)}$, Ria Asih Aryani Soemitro ${ }^{1, b)}$ \& Hitapriya Suprayitno ${ }^{1, c)}$ \\ ${ }^{1)}$ Departement Teknik Sipil, Institut Teknologi Sepuluh Nopember (ITS), Surabaya \\ 2) Jurusan Teknik Sipil, Universitas Negeri Surabaya (UNESA), Surabaya \\ Koresponden : a) anitasusanti.pasmar@gmail.com, ${ }^{\text {b) }}$ ria@ce.its.ac.id \& \\ ${ }^{\text {c) }}$ suprayitno.hita@gmail.com
}

\begin{abstract}
ABSTRAK
Infrastruktur dan fasilitas adalah komponen penting bagi kehidupan manusia. Kedua komponen tersebut harus direncanakan, dirancang, dibangun, dan dikelola dengan baik sesuai dengan prinsip-prinsip Manajemen Aset Infrastruktur dan Fasilitas. Salah satu bentuk fasilitas transportasi perkotaan adalah Kereta Api Komuter. Keberadaan layanan kereta api komuter di Kota Surabaya masih belum tersebar merata di seluruh wilayah. Maka dari itu diperlukan penelitian tentang perbandingan karakteristik perilaku perjalanan penumpang KA Komuter Surabaya. Metode penelitian dilakukan berdasarkan hasil survey wawancara kepada penumpang KA Komuter SULAM dan SUPOR. Tujuan dilakukannya penelitian ini adalah dihasilkannya data karakteristik tipikal perilaku perjalanan penumpang KA Komuter Surabaya, ditinjau dari data maksud perjalanan, moda hubung Ke dan Dari. Manfaat penelitian dapat dijadikan data acuan dalam merencanakan perhitungan prediksi kebutuhan perjalanan penumpang KA Komuter Surabaya di wilayah yang belum terlayani. Hasil penelitian dapat disampaikan bahwa secara umum hasil perbandingan karakteristik maksud perjalanan, moda perjalanan hubung ke dan dari antara penumpang KA Komuter Surabaya SULAM dan SUPOR memiliki kemiripan hasil. Maksud perjalanan penumpang sama-sama didominasi oleh Bekerja dan Kuliah. Nilai sintesa Bekerja sebesar 45,8\%. Nilai sintesa moda hubung Ke-, didominasi oleh pemakaian Sepeda Motor dengan cara Diantar sebesar 52\%. Nilai sintesa moda hubung Dari didominasi oleh Ojek Online sebesar $37,2 \%$.
\end{abstract}

Kata Kunci : manajemen aset infrastruktur dan fasilitas, kereta api komuter, perilaku perjalanan, perbandingan, sintesa

\section{LATAR BELAKANG}

Fasilitas adalah komponen penting yang harus direncanakan, dirancang, dibangun, dan dikelola dengan baik sesuai dengan prinsip-prinsip Manajemen Aset Infrastruktur dan Fasilitas (MAIF). Angkutan Umum Komuter merupakan Fasilitas Vital bagi kehidupan suatu Aglomerasi. MAIF harus didasarkan pada pengetahuan yang baik atas karakteristik fasilitas yang sedang dikelola dan dibahas. Karakteristik fasilitas berbeda satu dengan yang lainnya dan harus dapat dipahami dengan baik tipe, klas, fungsi, struktur, ekonomi, siklus hidup, operasi, pemeliharaan dan penghapusan (Soemitro \& Suprayitno, 2018; Suprayitno \& 
Soemitro, 2018). Berpijak pada uraian di atas, maka pengetahuan tentang Perilaku Perjalanan pada suatu Layanan Angkutan Umum perlu untuk diketahui dengan baik (Soemitro \& Suprayitno, 2018).

Perencanaan dan pembangunan layanan Angkutan Massal Cepat (AMC) sebagai salah satu Fasilitas Perkotaan di wilayah perkotaan sedang banyak dilakukan ol.eh Pemerintah Indonesia. (Upa, Suprayitno \& Ryansyah 2018). Salah satu bentuk layanan AMC tersebut adalah Kereta Api Komuter, Bus Rapid Transit (BRT, dan yang lain. Perencanaan layanan KA Komuter harus direncanakan dengan baik sesuai dengan prediksi kebutuhan jumlah penumpang. Hal tersebut di atas, sudah pernah dilakukan oleh peneliti terdahulu dalam merencanakan pengembangan layanan Bis Kota. Data yang dibutuhkan untuk mendukung perencanaan layanan operasional Bis Kota di atas adalah data karakteristik pelaku dan data karakteristik perilaku perjalanan (Suprayitno \& Upa 2017; Suprayitno \& Ryansyah 2018).

Pembahasan penelitian yang menggunakan data karakteristik perilaku perjalanan penumpang KA Komuter, hanya sebatas tentang pengukuran kinerja pelayanan KA Komuter (Yosrtizal et al, 2017; Nugraha \& Sarjito, 2016), moda sebelum dan sesudah yang digunakan pada saat menuju dan meninggalkan stasiun, serta alasan memilih menggunakan KA Komuter (Setiawan, 2006), perbandingan tingkat kejenuhan antara pengemudi kendaraan pribadi (mobil) dengan pengguna KA Komuter (Wener et al, 2011), perbandingan pengukuran kinerja pelayanan metroline di Mumbai India dengan menggunakan 2 metode survey, yaitu RV (Revealed Survey) dan SP (Stated Preference) (Sohoni et al, 2017).

Penelitian lainnya membahas tentang jarak perjalanan hubung dengan menggunakan sepeda motor dari lokasi pemukiman $<400$ meter menuju ke (Access) terminal BRT (Bus Rapid Transit) membutuhkan waktu 1 menit, sedangkan dari lokasi pemukiman $>400$ meter menuju ke (Access) membutuhkan waktu 2 menit. Jarak perjalanan dari terminal BRT (Egress) menuju ke lokasi tujuan dengan jarak 150 meter membutuhkan waktu 2 menit (Satiennam et al, 2016). Penelitian lainnya membahas tentang jarak perjalanan penumpang BRT Mamminasata di Kota Makasar pada koridor 2 dan koridor 3 memiliki variasi interval jarak perjalanan menuju Ke (Access) sekitar $2 \mathrm{Km}$ dan meninggalkan (Egress) BRT Mamminasata sekitar 0.5 Km (Suprayitno \& Upa, 2016).

Berpijak pada uraian di atas, maka dapat disimpulkan bahwa data karakteristik perilaku perjalanan merupakan data dasar dalam merencanakan dan mengembangkan layanan AMC di wilayah perkotaan, Hasil penelitian terdahulu data karakteristik perilaku perjalanan digunakan untuk menghitung kebutuhan jumlah armada dan kebutuhan jumlah perjalanan penumpang (Upa, Suprayitno \& Ryansyah 2018). Perhitungan prediksi jumlah penumpang merupakan bagian dari permodelan transportasi yang tentunya juga membutuhkan data karakteristik perilaku perjalanan, yaitu data karakteristik pelaku dan perilaku perjalanan (Suprayitno \& Ryansyah 2018).

Oleh karena itu, penelitian tentang karakteristik perilaku perjalanan penumpang KA Komuter SULAM dan KA Komuter SUPOR beserta perbandingan dan sintesanya penting untuk dilakukan. Hal ini juga perlu dilakukan mengingat bahwa layanan KA Komuter belum tersebar merata di seluruh wilayah Kota Surabaya dan sekitarnya (Susanti, Soemitro \& Suprayitno, 2017). Pembahasan mengenai perbandingan dan sintesis layanan Bis Kota sudah pernah dilakukan (Suprayitno \& Upa 2017; Suprayitno \& Ryansyah 2018; Upa, Suprayitno \& Ryansyah, 2018). Akan tetapi pembahasan mengenai perbandingan karakteristik perilaku perjalanan (maksud perjalanan dan moda hubung) layanan KA Komuter belum pernah dilakukan.

Penelitian ini hanya membahas tentang nilai, perbandingan, sintesa dan komulatif karakteristik maksud perjalanan, moda hubung Ke, dan moda hubung Dari. 
(e)ISSN 2615-1847 (p)ISSN 2615-1839

Jurnal Manajemen Aset Infrastruktur \& Fasilitas - Vol. 4, No. 3, Juli 2020

\section{STUDI PUSTAKA}

\section{Perilaku Perjalanan}

Perilaku perjalanan adalah tingkah laku manusia dalam melakukan perjalanannya dari asal ke tujuan. Pada penelitian transportasi, data yang diperoleh dari survei wawancara kepada penumpang di dalamnya mengandung pertanyaan mengenai karakteristik pelaku perjalanan dan karakteristik perilaku perjalanan. Data-data yang termasuk bagian dari karakteristik pelaku perjalanan antara lain adalah sebagai berikut: usia, jenis kelamin, pekerjaan, pendidikan, Data-data yang termasuk bagian dari karakteristik perilaku perjalanan meliputi beberapa hal sebagai berikut, yaitu: maksud perjalanan, moda pengumpan, frekuensi, moda sebelumnya, jarak dan waktu tempuh (Suprayitno dkk, 2006; Curtis \& Perkins, 2006; Kim et al, 2016; Feng et al, 2017; Suprayitno, Upa \& Ryansyah, 2018; Suprayitno \& Ryansyah, 2018, Suprayitno \& Upa 2017).

\section{Karakteristik Pelaku dan Perilaku Perjalanan Pengguna Bis Mamminasata Makassar}

Hasil penelitian mengenai karakteristik pelaku dan perilaku perjalanan penumpang Bis Trans Mamminasata ditinjau dari aspek Maksud Perjalanan didominasi untuk Bekeja sebesar 50\% dan untuk Sekolah sebesar 50\%. Karakteristik Moda Hubung Sebelum Beralih, didominasi oleh Moda Angkot sebesar 76\% dan Sepeda Motor sebesar 24\%. Karakteristik Jarak Hubung Ke, didominasi oleh jarak $(0-2 \mathrm{Km})$ sebesar $48 \%$. Moda Hubung yang digunakan Ke halte asal, didominasi oleh Sepeda Motor (51\%) dan Angkutan Umum (19\%). Jarak Hubung Dari, didominasi oleh jarak $(0,0-0,5 \mathrm{Km})$ lebih pendek dibandingkan dengan jarak hubung Ke. Moda Hubung Dari, didominasi oleh Jalan Kaki (71\%) dan Becak (18\%) (Suprayitno \& Upa, 2017).

\section{Karakteristik Pelaku dan Perilaku Perjalanan Pengguna Bis Trans Koetaradja}

Hasil penelitian mengenai karakteristik pelaku dan perilaku perjalanan penumpang Bis Trans Koetaradja dapat ditinjau dari aspek Maksud Perjalanan, Jarak Perjalanan Hubung Ke dan Jarak Perjalanan Hubung Dari. Maksud Perjalanan penumpang Bis Trans Koetaradja didominasi untuk Bekerja (55\%) dan Belanja (25\%). Karakteristik Moda Hubung Sebelum Beralih ke Bis Trans Koetaradja, didominasi oleh Angkutan Umum (80\%) dan Sepeda Motor (20\%). Jarak Hubung Ke sampai sejauh 1,5 Km dan didominasi dengan Berjalan Kaki (90\%). Jarak Hubung Dari sampai sejauh $1 \mathrm{Km}$ dan didominasi didominasi dengan Berjalan Kaki (100\%) (Suprayitno \& Ryansyah 2018).

\section{Perbandingan dan Sintesa Perilaku Perjalanan Pengguna Bis Mamminasata Makassar dengan Bis Trans Koetaradja di Aceh}

Hasil penelitian Karakteristik Perilaku Perjalanan pengguna Bis Trans Mamminasata Makassar mirip dengan Perilaku Perjalanan pengguna Bis Trans Koetaradja di Aceh. Hasil analisis dapat disampaikan bahwa Maksud Perjalanan didominasi oleh Bekerja dan Kuliah pada angka Komulatif 87,5\%. Penggunaan Moda Sebelum Beralih didominasi oleh moda Angkot Tradisional (78\%) dan Sepeda Motor (22\%). Perjalanan Hubung Ke didominasi oleh nilai $0-1,5 \mathrm{Km}$ pada angka Komulatif $75 \%$. Aspek Moda Ke didominasi dengan Berjalan Kaki dan Sepeda Motor pada angka Komulatif 77\%. Perjalanan Hubung Dari didominasi oleh nilai $0-1 \mathrm{Km}$ pada angka komulatif 93,5\%. Aspek Moda Hubung Dari didominasi dengan Berjalan Kaki pada angka Komulatif 85,5\% (Upa, Suprayitno \& Ryansyah 2018). 


\section{METODE PENELITIAN}

Penelitian ini membandingkan hasil karakteristik perilaku perjalanan penumpang KA Komuter SUPOR (Surabaya-Porong) dan KA Komuter SULAM (Surabaya-Lamongan). Data karakteristik tersebut diperoleh dari hasil survei wawancara di dalam KA Komuter pada jam keberangkatan pagi hari. Pada layanan KA Komuter SULAM, survey dilakukan dari arah Lamongan-Surabaya, sedangkan pada layanan KA Komuter SUPOR, survey dilakukan dari arah Surabaya-Porong. Hasil dari survei wawancara diperoleh data sejumlah 280 penumpang KA Komuter SULAM dan data sejumlah 448 penumpang KA Komuter SUPOR. Tujuan dilakukannya perbandingan karakteristik perilaku perjalanan dari kedua KA Komuter tersebut di atas, untuk mengetahui apakah terjadi perbedaan karakteristik antara penumpang KA Komuter SULAM dengan KA Komuter SUPOR. Hasil perbandingan karakteristik apabila memiliki nilai yang jauh berbeda, maka tidak dapat disintesa. Hasil perbandingan karakteristik yang memiliki kesamaan hasil nilai (tidak berbeda jauh), maka dapat disintesa. Hasil perbandingan, sintesa, dan komulatif dilakukan untuk mengetahui gambaran umum Karakteristik Perilaku Perjalanan KA Komuter Surabaya, ditinjau dari aspek Maksud Perjalanan, Moda Hubung Ke, dan Moda Hubung Dari saja. Hasil penelitian ditinjau dari ketiga aspek di atas, kedepannya dapat digunakan sebagai Data Acuan Pengembangan Layanan KA Komuter, dengan menambahkan beberapa data survei Karakteristik Pelaku dan Perilaku Perjalanan lainnya. Metode penelitian ditunjukkan pada Gambar 1.

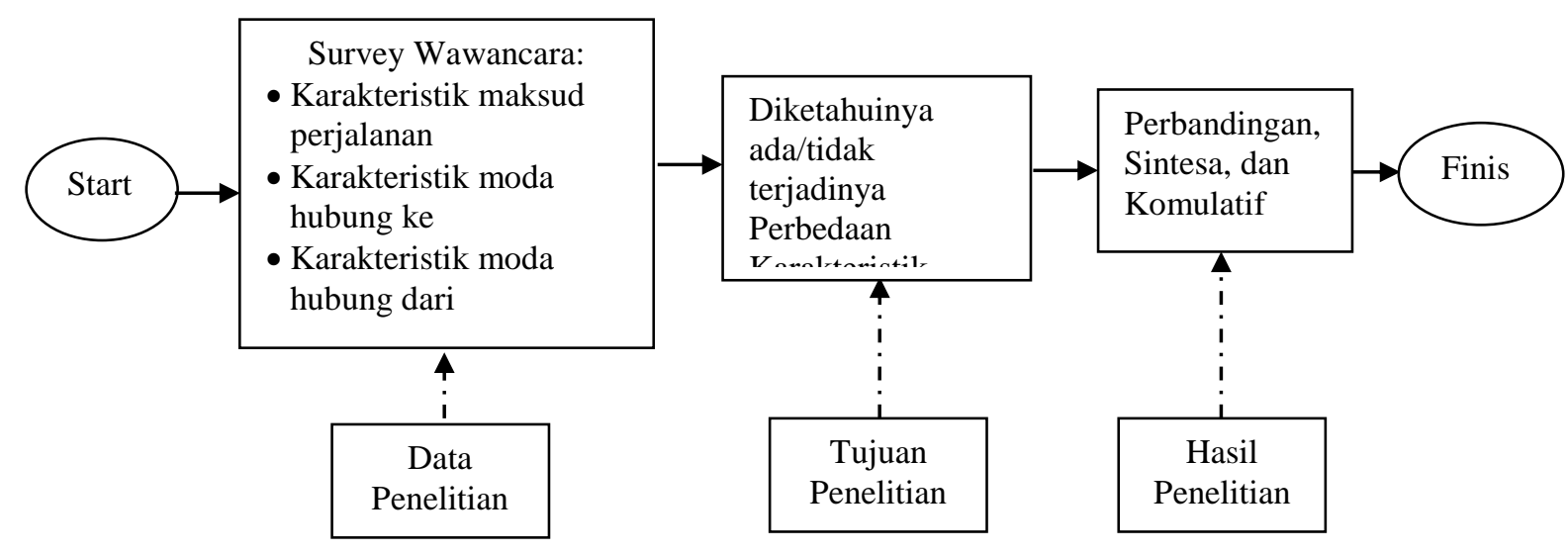

Gambar 1. Metode Penelitian

\section{HASIL DAN PEMBAHASAN}

\section{Karakteristik Maksud Perjalanan Penumpang KA Komuter Surabaya}

Karakteristik Maksud Perjalanan penumpang KA Komuter SULAM, didominasi untuk Kuliah (40,7\%), Bekerja (30,4\%), dan Berkunjung (9,3\%). Karakteristik Maksud Perjalanan penumpang KA Komuter SUPOR, didominasi untuk Bekerja $(61,2 \%)$, Kuliah (16,7\%), Berkunjung (8,9\%), dan Periksa Kesehatan (5,1\%). Maksud perjalanan kedua jenis KA Komuter di atas, tidak memiliki kemiripan hasil yang ditunjukkan pada Tabel 1 dan Gambar 2. Dengan demikian Karakteristik Maksud Perjalanan kedua KA Komuter tersebut tidak dapat disintesakan untuk mendapatkan suatu nilai yang bisa dipakai secara umum bagi keduanya.

Pada makalah ini disampaikan Karakteristik Maksud Perjalanan penumpang kedua KA Komuter Surabaya sebagai sebuah ilustrasi. Secara keseluruhan Maksud Perjalanan, didominasi untuk Bekerja (49,3\%), Kuliah (26\%), dan Berkunjung (9,1\%) dengan total komulatif sebesar $84,3 \%$. Perhitungan Ilustrasi Sintesa ditunjukkan pada Tabel 2 dan Gambar 3. 
Tabel 1. Karakteristik Maksud Perjalanan

\begin{tabular}{clcccc}
\hline \multirow{2}{*}{ No. } & \multirow{2}{*}{$\begin{array}{c}\text { Maksud } \\
\text { Perjalanan }\end{array}$} & \begin{tabular}{c} 
SULAM \\
Jumlah \\
\cline { 3 - 6 }
\end{tabular} & $\begin{array}{c}\text { Persentase } \\
\text { (orang) }\end{array}$ & $\begin{array}{c}\text { Jumlah } \\
\text { (orang) }\end{array}$ & $\begin{array}{c}\text { Persentase } \\
(\boldsymbol{\%})\end{array}$ \\
\hline 1 & Bekerja & 85 & 30,4 & 274 & 61,2 \\
2 & Kuliah & 114 & 40,7 & 75 & 16,7 \\
3 & Berkunjung & 26 & 9,3 & 40 & 8,9 \\
4 & Periksa Kesehatan & 4 & 1,4 & 23 & 5,1 \\
5 & Sekolah & 7 & 2,5 & 10 & 2,2 \\
6 & Rekreasi & 8 & 2,9 & 3 & 0,7 \\
7 & Berdagang & 9 & 3,2 & 2 & 0,4 \\
8 & Belanja & 6 & 2,1 & 1 & 0,2 \\
9 & Pulang Kerja & 0 & 0,0 & 1 & 0,2 \\
10 & Lain-Lain & 21 & 7,5 & 19 & 4,2 \\
\hline \multicolumn{2}{c}{ Total } & $\mathbf{2 8 0}$ & $\mathbf{1 0 0 , 0}$ & $\mathbf{4 4 8}$ & $\mathbf{1 0 0 , 0}$ \\
\hline
\end{tabular}

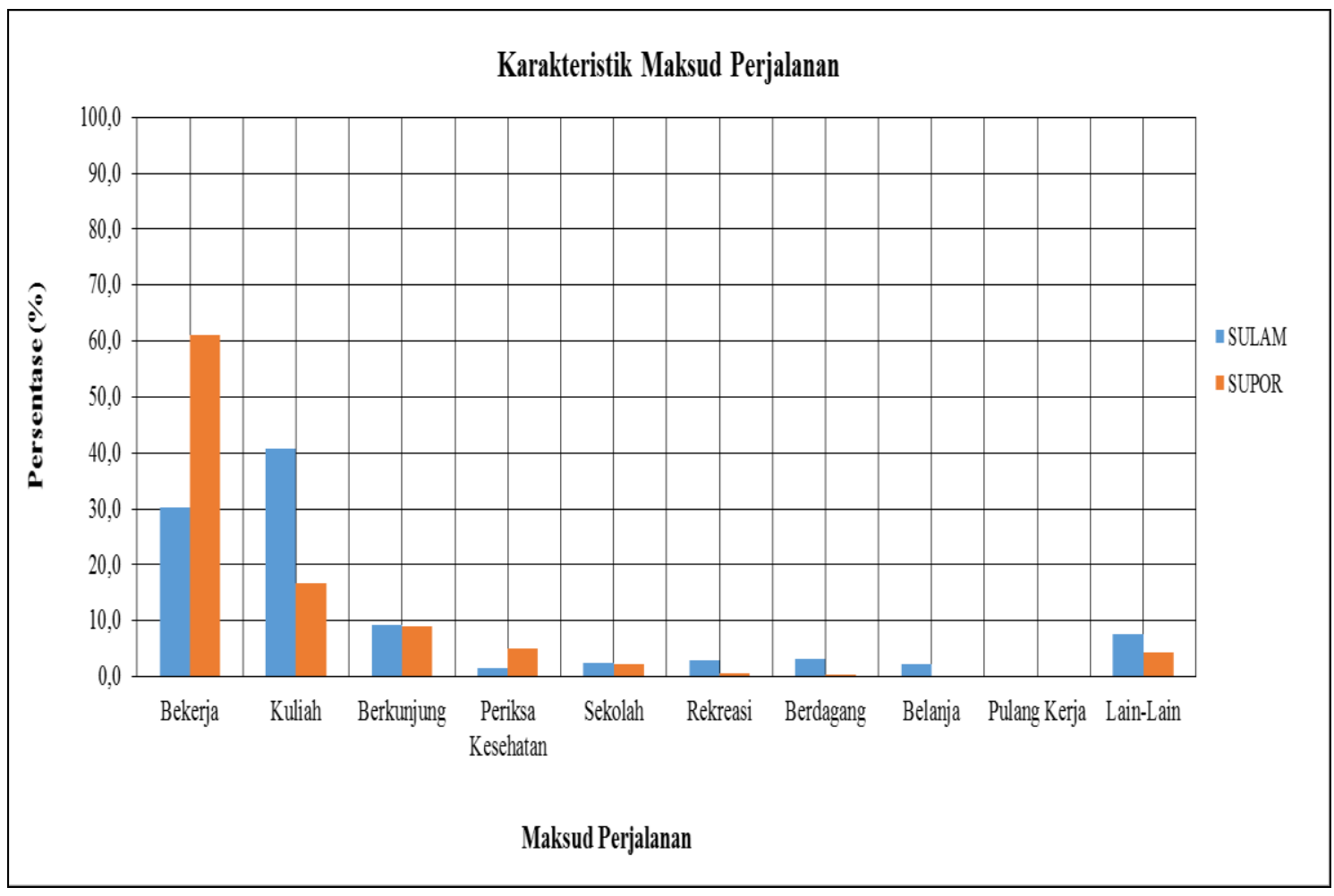

Gambar 2. Karakteristik Maksud Perjalanan Penumpang 
Tabel 2. Perbandingan dan Ilustrasi Sintesa dan Komulatif Maksud Perjalanan

\begin{tabular}{|c|c|c|c|c|c|c|c|c|}
\hline \multirow[b]{2}{*}{ No. } & \multirow[b]{2}{*}{$\begin{array}{c}\text { Maksud } \\
\text { Perjalanan }\end{array}$} & \multicolumn{2}{|c|}{ SULAM } & \multicolumn{2}{|c|}{ SUPOR } & \multicolumn{2}{|c|}{ Ilustrasi Sintesa } & \multirow[b]{2}{*}{$\begin{array}{c}\text { Komulatif } \\
(\%)\end{array}$} \\
\hline & & $\begin{array}{l}\text { Jumlah } \\
\text { (orang) }\end{array}$ & $\begin{array}{c}\text { Persentase } \\
(\%)\end{array}$ & $\begin{array}{l}\text { Jumlah } \\
\text { (orang) }\end{array}$ & $\begin{array}{c}\text { Persentase } \\
(\%)\end{array}$ & $\begin{array}{l}\text { Jumlah } \\
\text { (orang) }\end{array}$ & $\begin{array}{c}\text { Persentase } \\
(\%)\end{array}$ & \\
\hline 1 & Bekerja & 85 & 30,4 & 274 & 61,2 & 359 & 49,3 & 49,3 \\
\hline 2 & Kuliah & 114 & 40,7 & 75 & 16,7 & 189 & 26,0 & 75,3 \\
\hline 3 & Berkunjung & 26 & 9,3 & 40 & 8,9 & 66 & 9,1 & 84,3 \\
\hline 4 & Periksa Kesehatan & 4 & 1,4 & 23 & 5,1 & 27 & 3,7 & 88,0 \\
\hline 5 & Sekolah & 7 & 2,5 & 10 & 2,2 & 17 & 2,3 & 90,4 \\
\hline 6 & Rekreasi & 8 & 2,9 & 3 & 0,7 & 11 & 1,5 & 91,9 \\
\hline 7 & Berdagang & 9 & 3,2 & 2 & 0,4 & 11 & 1,5 & 93,4 \\
\hline 8 & Belanja & 6 & 2,1 & 1 & 0,2 & 7 & 1,0 & 94,4 \\
\hline 9 & Pulang Kerja & 0 & 0,0 & 1 & 0,2 & 1 & 0,1 & 94,5 \\
\hline 10 & Lain-Lain & 21 & 7,5 & 19 & 4,2 & 40 & 5,5 & 100,0 \\
\hline & Total & 280 & 100,0 & 448 & 100,0 & 728 & 100,0 & \\
\hline
\end{tabular}

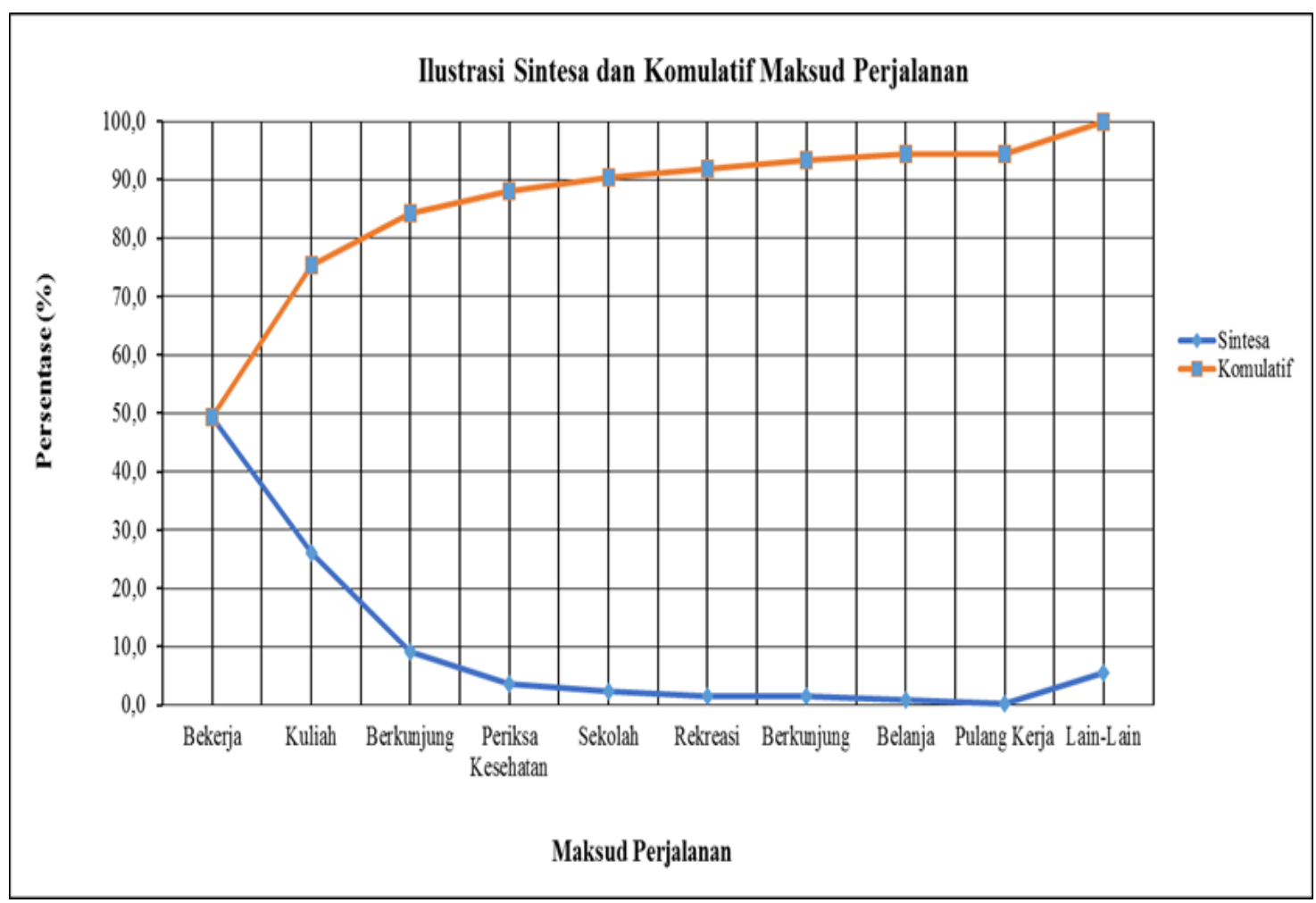

Gambar 3. Ilustrasi Sintesa dan Komulatif Maksud Perjalanan Penumpang

\section{Perbandingan dan Sintesa Moda Hubung Ke (Access) Penumpang KA Komuter Surabaya}

Pada penelitian ini, data yang digunakan adalah data moda perjalanan hubung ke (Access) penumpang KA Komuter SULAM dan KA Komuter SUPOR. Data moda hubung menuju ke stasiun asal KA Komuter SULAM merupakan data hasil penelitian sebelumnya (Susanti, Soemitro \& Suprayitno, 2019). Hasil survei wawancara kepada penumpang, diketahui bahwa jenis moda hubung yang digunakan dapat dibedakan menjadi 3 jenis moda, yaitu: 1). kendaraan pribadi, 2). angkutan umum (trayek), 3) angkutan umum (non trayek). Kendaraan pribadi terdiri dari sepeda motor diantar, sepeda motor dibawa sendiri, jalan kaki, mobil diantar, sepeda ontel, dan mobil dibawa sendiri. Angkutan umum (Trayek) terdiri dari 
mikrolet/lyn, bus kota, dan bus sedang. Angkutan umum (non trayek) terdiri dari ojek online, becak, ojek tradisional, taksi online, dan taksi konvensional.

Moda Hubung yang digunakan oleh 280 penumpang KA Komuter SULAM, didominasi oleh Sepeda Motor dengan cara Diantar sebesar 48,6\% dan Sepeda Motor dengan cara Dibawa Sendiri sebesar 37,5\%. Moda hubung yang digunakan oleh penumpang KA Komuter SUPOR, didominasi oleh Sepeda Motor dengan cara Diantar sebesar 55,4\% dan Sepeda Motor dengan cara Dibawa Sendiri sebesar 21,9\%.

Moda hubung yang digunakan oleh penumpang KA Komuter SULAM dan KA Komuter SUPOR menuju Ke stasiun asal, memiliki kemiripan hasil yaitu sama-sama didominasi oleh Sepeda Motor dengan cara Diantar (52\%) dan Sepeda Motor dengan cara Dibawa Sendiri $(29,7 \%)$ dengan total komulatif sebesar 81,7\%. Hasil perbandingan karakteristik ditinjau dari moda hubung Ke secara umum sama, sehingga dapat disintesakan untuk diketahui nilai rata-rata dari kedua jenis KA di atas. Hasil perbandingan, sintesa, dan komulatif disampaikan pada Tabel 3, Gambar 4, dan Gambar 5.

Tabel 3. Perbandingan, Sintesa, dan Komulatif Moda Hubung Ke Stasiun Asal

\begin{tabular}{|c|c|c|c|c|c|c|c|}
\hline \multirow[b]{2}{*}{ No. } & \multirow{2}{*}{$\begin{array}{l}\text { Moda Hubung } \\
\text { Ke Stasiun Asal }\end{array}$} & \multicolumn{2}{|c|}{ SULAM } & \multicolumn{2}{|c|}{ SUPOR } & \multirow{2}{*}{$\begin{array}{c}\text { Sintesa } \\
(\%)\end{array}$} & \multirow{2}{*}{$\begin{array}{c}\text { Komulatif } \\
(\%)\end{array}$} \\
\hline & & $\begin{array}{l}\text { Jumlah } \\
\text { (orang) }\end{array}$ & $\begin{array}{c}\text { Persentase } \\
(\%)\end{array}$ & $\begin{array}{l}\text { Jumlah } \\
\text { (orang) }\end{array}$ & $\begin{array}{c}\text { Persentase } \\
(\%)\end{array}$ & & \\
\hline 1. & $\begin{array}{l}\text { Sepeda Motor } \\
\text { Diantar }\end{array}$ & 136 & 48,6 & 248 & 55,4 & 52,0 & 52,0 \\
\hline 2. & $\begin{array}{l}\text { Sepeda Motor } \\
\text { Dibawa Sendiri }\end{array}$ & 105 & 37,5 & 98 & 21,9 & 29,7 & 81,7 \\
\hline 3. & Jalan Kaki & 2 & 0,7 & 44 & 9,8 & 5,3 & 86,9 \\
\hline 4. & Mobil Diantar & 6 & 2,1 & 15 & 3,3 & 2,7 & 89,7 \\
\hline 5. & Sepeda Ontel & 1 & 0,4 & 21 & 4,7 & 2,5 & 92,2 \\
\hline 6. & Mikrolet / Lyn & 6 & 2,1 & 10 & 2,2 & 2,2 & 94,4 \\
\hline 7. & Bus Kota & 5 & 1,8 & 5 & 1,1 & 1,5 & 95,8 \\
\hline 8. & Ojek Online & 8 & 2,9 & 1 & 0,2 & 1,5 & 97,4 \\
\hline 9. & Becak & 4 & 1,4 & 3 & 0,7 & 1,0 & 98,4 \\
\hline 10. & Ojek Tradisional & 3 & 1,1 & 3 & 0,7 & 0,9 & 99,3 \\
\hline 11. & Taksi Online & 3 & 1,1 & 0 & 0,0 & 0,5 & 99,8 \\
\hline 12. & Bus Sedang & 1 & 0,4 & 0 & 0,0 & 0,2 & 100,0 \\
\hline 13. & $\begin{array}{l}\text { Taksi } \\
\text { Konvensional }\end{array}$ & 0 & 0,0 & 0 & 0,0 & 0,0 & 100,0 \\
\hline 14. & $\begin{array}{l}\text { Mobil Dibawa } \\
\text { Sendiri }\end{array}$ & 0 & 0,0 & 0 & 0,0 & 0,0 & 100,0 \\
\hline & Total & 280 & 100,0 & 448 & 100,0 & 100,0 & \\
\hline
\end{tabular}


(e)ISSN 2615-1847 (p)ISSN 2615-1839

Jurnal Manajemen Aset Infrastruktur \& Fasilitas - Vol. 4, No. 3, Juli 2020

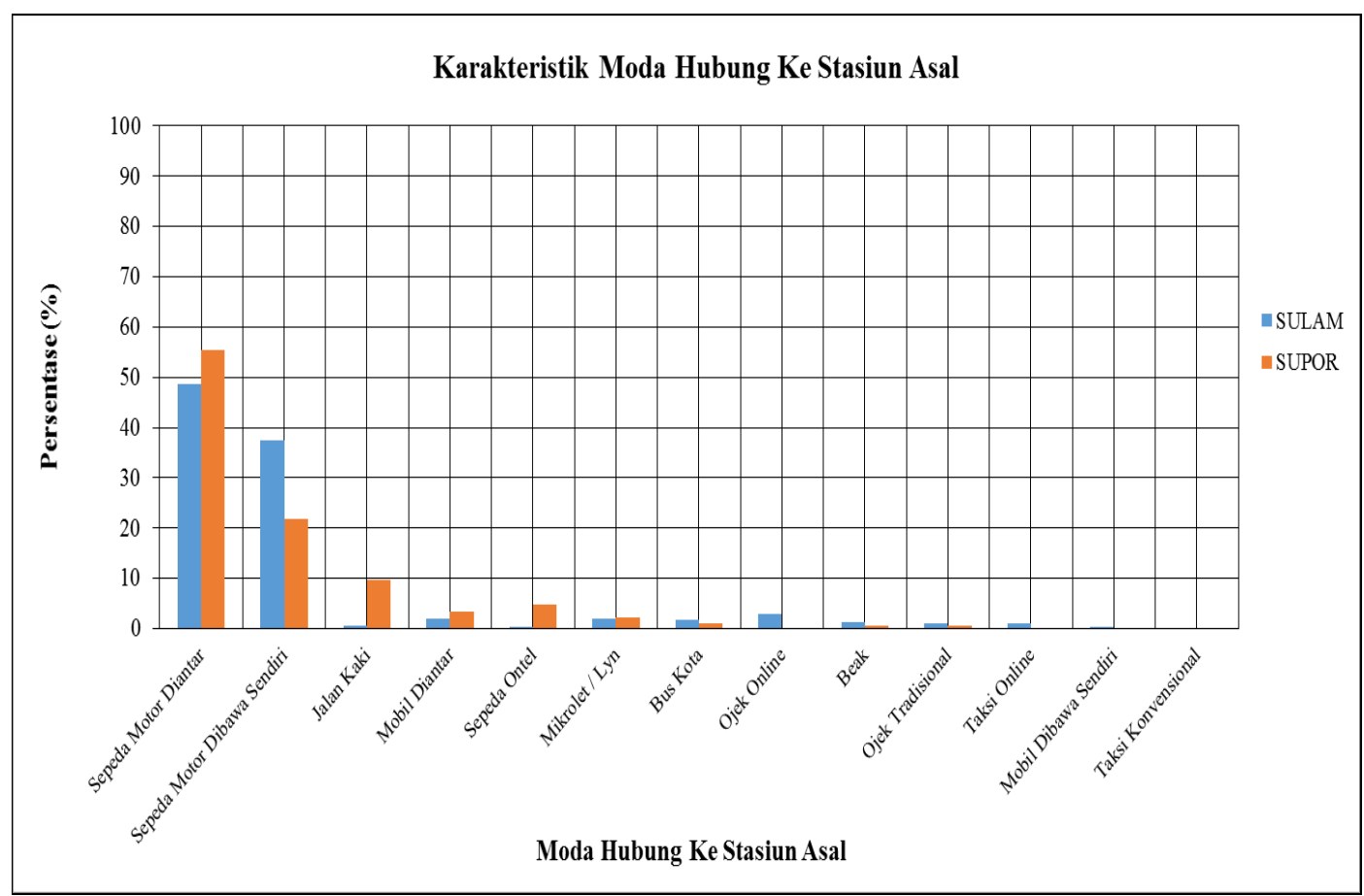

Gambar 4. Perbandingan Karakteristik Moda Hubung Ke - Penumpang KA Komuter Surabaya

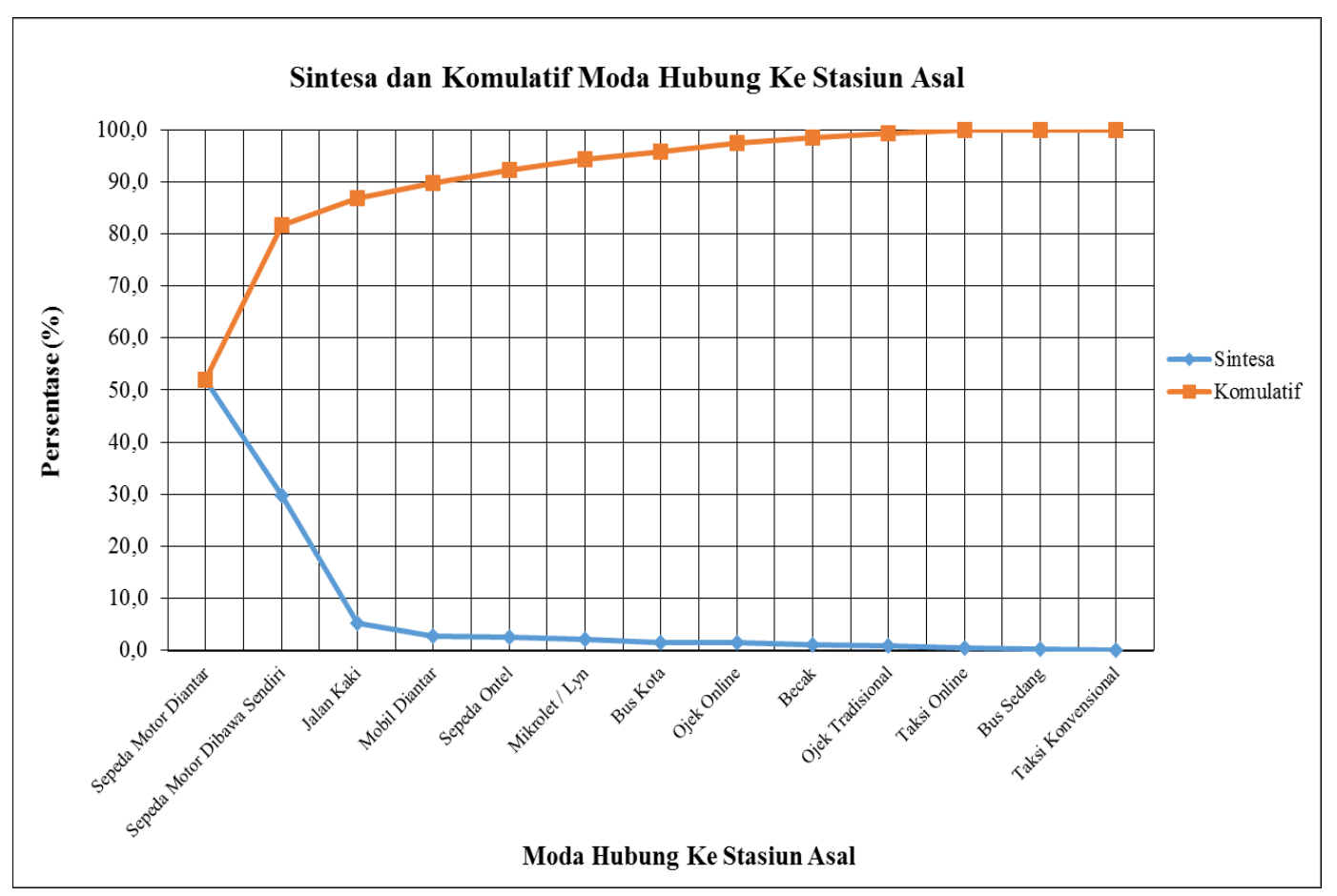

Gambar 5. Sintesa dan Komulatif Moda Hubung Ke- Penumpang KA Komuter Surabaya 


\section{Karakteristik Moda Perjalanan Hubung Dari (Egress) Penumpang KA Komuter Surabaya}

Data moda perjalanan hubung dari (Egress) adalah moda yang digunakan oleh penumpang dari stasiun tujuan menuju ke lokasi tujuan. Karakteristik Perilaku Perjalanan penumpang KA Komuter SULAM dan SUPOR ditinjau dari aspek Moda Hubung Dari memiliki perbedaan hasil.

Moda Hubung Dari Stasiun Tujuan berdasarkan jawaban penumpang KA Komuter SULAM, didominasi oleh Angkutan Umum (Non Trayek) - Ojek Online (43,6\%), Jalan Kaki $(18,6 \%)$, dan Mikrolet (10\%). Moda Hubung Dari Stasiun Tujuan berdasarkan jawaban penumpang KA Komuter SUPOR, didominasi dengan Berjalan Kaki $(37,1)$, Ojek Online $(30,8 \%)$, dan Mikrolet $(12,9)$. Hasil karakteristik Moda Hubung Dari, ditunjukkan pada Tabel 4 dan Gambar 6. Terjadinya perbedaan karakteristik di atas, maka Karakteristik Moda Hubung Dari kedua jenis KA Komuter tidak dapat disintesakan, sehingga tidak diperoleh suatu nilai yang dapat digunakan secara umum bagi keduanya.

Pada makalah ini, dapat disampaikan bahwa karakteristik Moda Hubung Dari untuk perhitungan nilai Sintesa ditunjukkan sebagai sebuah ilustrasi. Secara keseluruhan Moda Hubung Dari, didominasi oleh Ojek Online (35,7\%), Jalan Kaki (29,9\%), Mikrolet (11,8\%), Sepeda Motor Dibawa Sendiri $(8,8 \%)$, dan Taksi Online $(7,6 \%)$ dengan total komulatif sebesar 93,8\%. Perhitungan Ilustrasi Sintesa Moda Hubung Dari ditunjukkan pada Tabel 5 dan Gambar 7.

Tabel 4. Karakteristik Moda Hubung Dari Stasiun Tujuan

\begin{tabular}{|c|c|c|c|c|c|}
\hline \multirow[b]{2}{*}{ No. } & \multirow[b]{2}{*}{$\begin{array}{l}\text { Moda Hubung Ke } \\
\text { Stasiun Asal }\end{array}$} & \multicolumn{2}{|c|}{ SULAM } & \multicolumn{2}{|c|}{ SUPOR } \\
\hline & & $\begin{array}{l}\text { Jumlah } \\
\text { (orang) }\end{array}$ & $\begin{array}{c}\text { Persentase } \\
(\%)\end{array}$ & $\begin{array}{l}\text { Jumlah } \\
\text { (orang) }\end{array}$ & $\begin{array}{c}\text { Persentase } \\
(\%)\end{array}$ \\
\hline 1. & Ojek Online & 122 & 43,6 & 138 & 30,8 \\
\hline 2. & Jalan Kaki & 52 & 18,6 & 166 & 37,1 \\
\hline 3. & Mikrolet / Lyn & 28 & 10,0 & 58 & 12,9 \\
\hline 4. & $\begin{array}{l}\text { Sepeda Motor Dibawa } \\
\text { Sendiri }\end{array}$ & 19 & 6,8 & 45 & 10 \\
\hline 5. & Taksi Online & 33 & 11,8 & 22 & 4,9 \\
\hline 6. & $\begin{array}{l}\text { Sepeda Motor } \\
\text { Dijemput }\end{array}$ & 18 & 6,4 & 5 & 1,1 \\
\hline 7. & Sepeda Ontel & 4 & 1,4 & 4 & 0,9 \\
\hline 8. & Taksi Konvensional & 0 & 0,0 & 5 & 1,1 \\
\hline 9. & Becak & 2 & 0,7 & 2 & 0,4 \\
\hline 10. & Mobil Dijemput & 1 & 0,4 & 2 & 0,4 \\
\hline 11. & Ojek Tradisional & 1 & 0,4 & 1 & 0,2 \\
\hline 12. & Mobil Dibawa Sendiri & 0 & 0,0 & 0 & 0,0 \\
\hline 13. & Bus Sedang (Bison) & 0 & 0,0 & 0 & 0,0 \\
\hline 14. & Bus Kota & 0 & 0,0 & 0 & 0,0 \\
\hline & Total & 280 & 100,0 & 448 & 100,0 \\
\hline
\end{tabular}




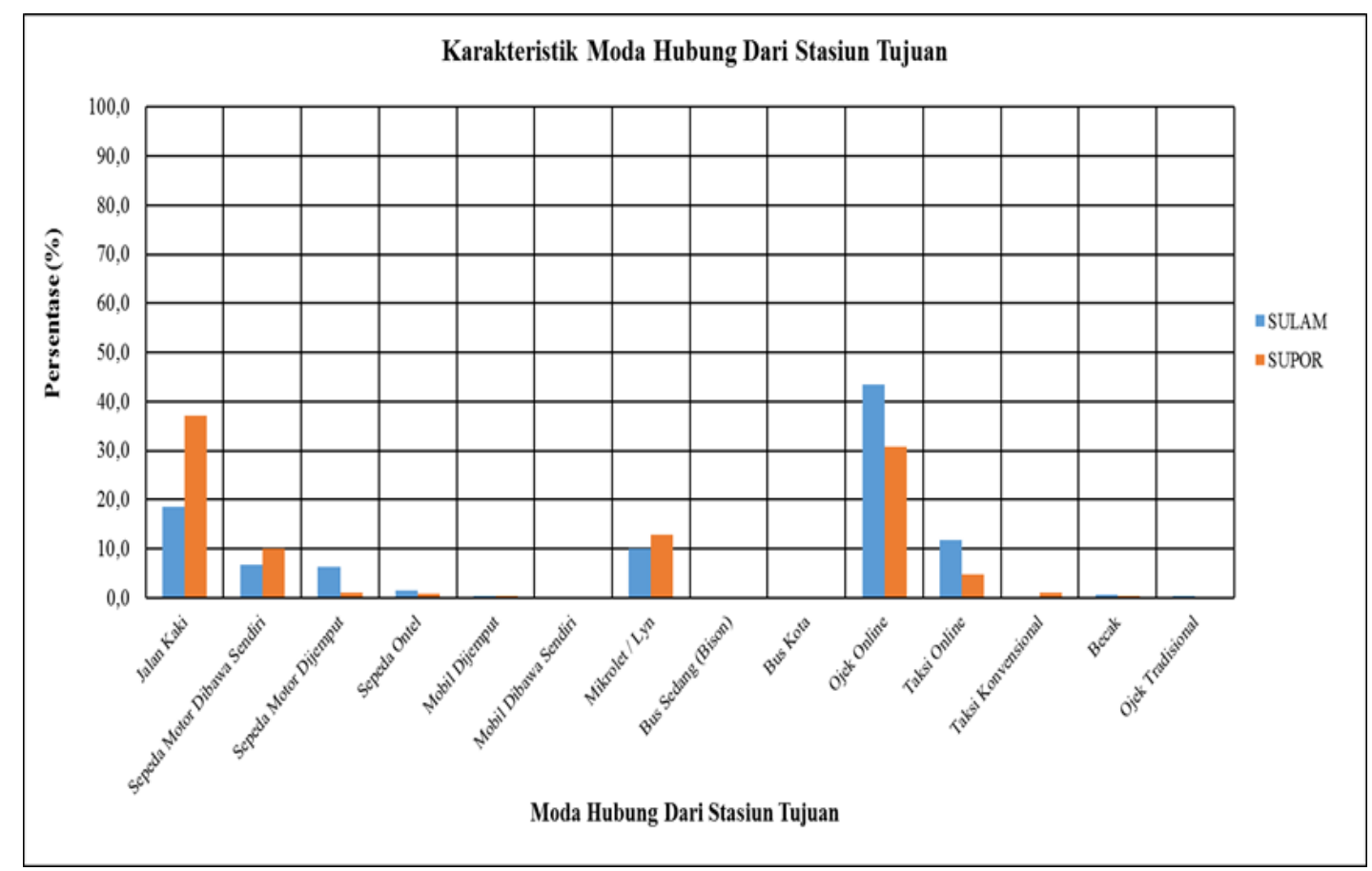

Gambar 6. Karakteristik Moda Hubung Dari - Penumpang KA Komuter Surabaya

Tabel 5. Perbandingan dan Ilustrasi Sintesa Karakteristik Moda Hubung Dari

\begin{tabular}{|c|c|c|c|c|c|c|c|c|}
\hline \multirow[b]{2}{*}{ No. } & \multirow{2}{*}{$\begin{array}{c}\text { Moda Hubung } \\
\text { Dari Stasiun } \\
\text { Tujuan } \\
\end{array}$} & \multicolumn{2}{|c|}{ SULAM } & \multicolumn{2}{|c|}{ SUPOR } & \multicolumn{2}{|c|}{ Ilustrasi Sintesa } & \multirow[b]{2}{*}{$\begin{array}{c}\text { Komulatif } \\
(\%)\end{array}$} \\
\hline & & $\begin{array}{l}\text { Jumlah } \\
\text { (orang) }\end{array}$ & $\begin{array}{c}\text { Persentase } \\
(\%)\end{array}$ & $\begin{array}{l}\text { Jumlah } \\
\text { (orang) }\end{array}$ & $\begin{array}{c}\text { Persentase } \\
(\%)\end{array}$ & $\begin{array}{l}\text { Jumlah } \\
\text { (orang) }\end{array}$ & $\begin{array}{c}\text { Persentase } \\
(\%)\end{array}$ & \\
\hline 1. & Ojek Online & 122 & 43,6 & 138 & 30,8 & 260 & 35,7 & 35,7 \\
\hline 2. & Jalan Kaki & 52 & 18,6 & 166 & 37,1 & 218 & 29,9 & 65,7 \\
\hline 3 . & Mikrolet / Lyn & 28 & 10 & 58 & 12,9 & 86 & 11,8 & 77,5 \\
\hline 4. & $\begin{array}{l}\text { Sepeda Motor } \\
\text { Dibawa Sendiri }\end{array}$ & 19 & 6,8 & 45 & 10 & 64 & 8,8 & 86,3 \\
\hline 5. & Taksi Online & 33 & 11,8 & 22 & 4,9 & 55 & 7,6 & 93,8 \\
\hline 6. & $\begin{array}{l}\text { Sepeda Motor } \\
\text { Dijemput }\end{array}$ & 18 & 6,4 & 5 & 1,1 & 23 & 3,2 & 97,0 \\
\hline 7. & Sepeda Ontel & 4 & 1,4 & 4 & 0,9 & 8 & 1,1 & 98,1 \\
\hline 8. & Taksi Konvensional & 0 & 0 & 5 & 1,1 & 5 & 0,7 & 98,8 \\
\hline 9. & Becak & 2 & 0,7 & 2 & 0,4 & 4 & 0,5 & 99,3 \\
\hline 10. & Mobil Dijemput & 1 & 0,4 & 2 & 0,4 & 3 & 0,4 & 99,7 \\
\hline 11. & Ojek Tradisional & 1 & 0,4 & 1 & 0,2 & 2 & 0,3 & 100,0 \\
\hline 12. & $\begin{array}{l}\text { Mobil Dibawa } \\
\text { Sendiri }\end{array}$ & 0 & 0 & 0 & 0 & 0 & 0,0 & 100,0 \\
\hline 13. & Bus Sedang (Bison) & 0 & 0 & 0 & 0 & 0 & 0,0 & 100,0 \\
\hline $14 .$. & Bus Kota & 0 & 0 & 0 & 0 & 0 & 0,0 & 100,0 \\
\hline & Total & 280 & 100 & 448 & 100 & 728 & 100,0 & \\
\hline
\end{tabular}




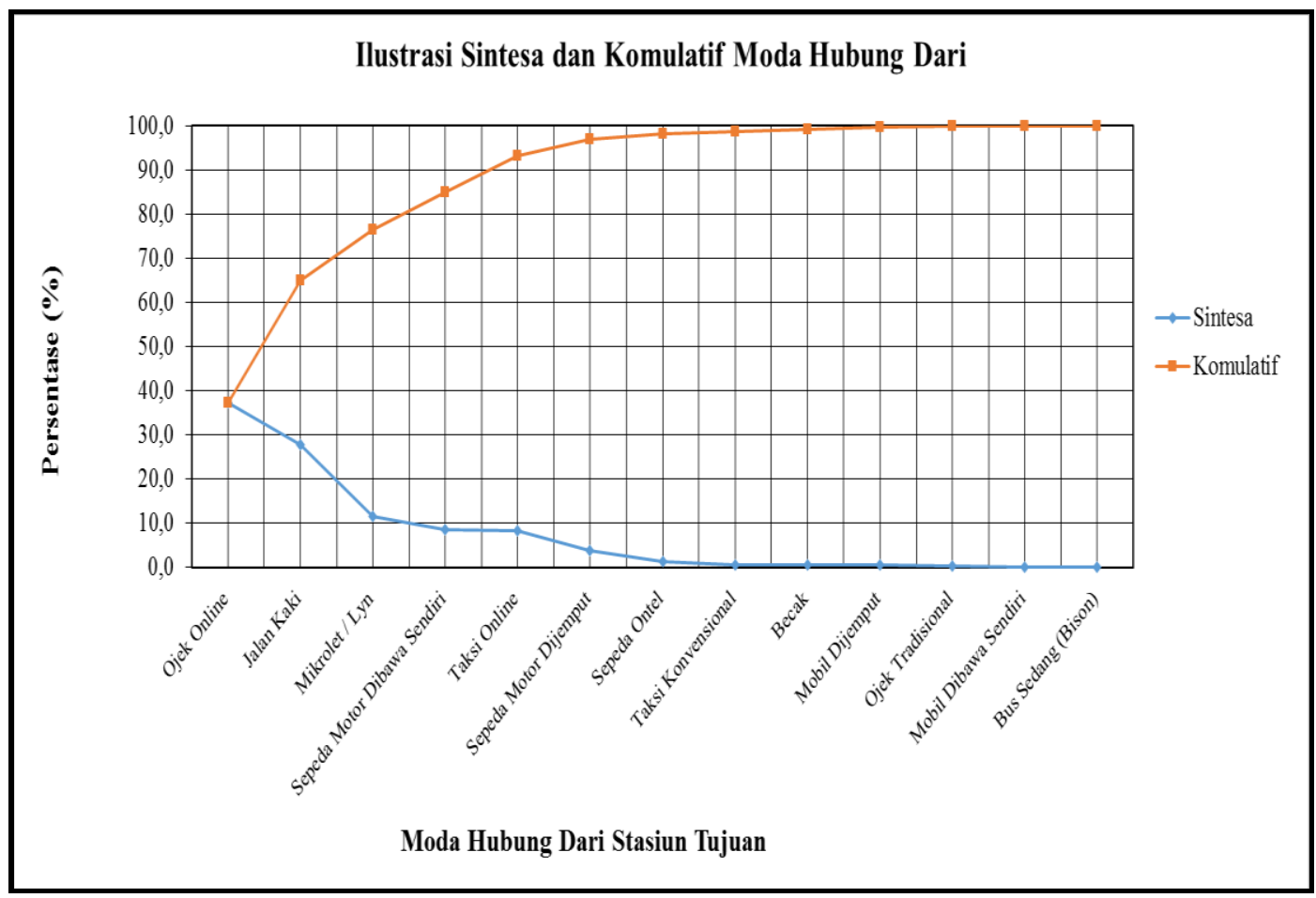

Gambar 7. Ilustrasi Sintesa dan Komulatif Moda Hubung Dari - KA Komuter Surabaya

\section{KESIMPULAN}

Penelitian ini mampu menghasilkan beberapa hal penting tentang Perbandingan dan Sintesa Karakteristik KA Komuter Surabaya.

- Secara umum hasil perhitungan karakteristik maksud perjalanan penumpang, moda hubung ke dan moda hubung dari KA Komuter SUPOR dan SULAM memiliki kemiripan hasil. Kemiripan hasil karakteristik tersebut dijelaskan sebagai berikut :

- Hasil Karakteristik Maksud Perjalanan penumpang KA Komuter SULAM, didominasi untuk Kuliah (40,7\%), sedangkan Karakteristik Maksud Perjalanan penumpang KA Komuter SUPOR, didominasi untuk Bekerja (61,2\%). Maksud perjalanan kedua jenis KA Komuter di atas, tidak memiliki kemiripan hasil, sehingga tidak dapat disintesakan. Secara keseluruhan Maksud Perjalanan, didominasi untuk Bekerja (49,3\%), Kuliah (26\%), dan Berkunjung $(9,1 \%)$ dengan total komulatif sebesar $84,3 \%$.

- Hasil Karakteristik Moda Hubung Ke dari kedua jenis KA Komuter SULAM dan SUPOR, sama-sama didominasi oleh pemakaian Sepeda Motor dengan cara Diantar dari lokasi asal menuju ke stasiun asal. Nilai sintesa Sepeda Motor Diantar (52\%) dan Sepeda Motor Dibawa Sendiri $(29,7 \%)$ dengan total komulatif sebesar $81,7 \%$.

- Hasil Karakteristik Moda Hubung Dari, ditinjau dari kedua jenis KA Komuter SULAM dan SUPOR, memiliki perbedaan hasil. Moda hubung yang digunakan oleh penumpang KA Komuter SULAM didominasi oleh Ojek Online (43,6\%), sedangkan moda hubung yang digunakan oleh penumpang KA Komuter SUPOR didominasi dengan Berjalan Kaki (37,1\%). Karakteristik Moda Hubung Dari tidak dapat disintesakan, karena memiliki perbedaan hasil. Secara keseluruhan karakteristik Moda Hubung Dari, didominasi oleh Ojek Online (35,7\%), Jalan Kaki (29,9\%), Mikrolet (11,8\%), Sepeda Motor Dibawa Sendiri (8,8\%), dan Taksi Online $(7,6 \%)$ dengan total komulatif sebesar $93,8 \%$. 
- Hasil penelitian ini dapat dikembangkan ke arah penyusunan Karakteristik Tipikal Perilaku Perjalanan KA Komuter Surabaya dengan menambah beberapa data penting tentang jarak hubung Ke dan jarak hubung Dari.

\section{DAFTAR PUSTAKA}

Curtis, C. \& Perkins, T. (2006). "Travel Behaviour". Urbanet Departement of Urban and Regional Planning, Curtin University.

Feng, J., Dijst, M., Wissink, B., Prillwitz, J. ( 2017). "Changing travel behavior in urban China: Evidence from Nanjing 2008-2011”. Transport Policy, 53, pp.1-10.

Kim, C. \& Parent, O. (2016). "Modeling individual travel behaviors based on intra-household interactions". Regional Science and Urban Economics, 57, 1-11.

Nugraha, W.A.N., \& Sarjito. (2017). "Arahan Peningkatan Pelayanan Kereta Komuter Surabaya-Lamongan Berdasarkan Prefensi Masyarakat”. Jurnal Teknik ITS, No. 2, Vol. 6, Hal.: 520-525.

Satiennam, T., Jaensisrisak, S., Satiennam, W. \& Detdamrong, S. (2016). "Potensial for Modal Shift by Passenger Car \& Motorcycle Users Towards Bus Rapid Transit (BRT) in an Asian Developing City". IATSS Research, 39, pp. 121-129.

Setiawan, R. (2005). "Karakteristik Pengguna KA Komuter Surabaya-Sidoarjo". Prosiding Seminar Nasional Perencanaan V, UPN, Surabaya.

Soemitro, R.A.A. \& Suprayitno, H. (2018). "Pemikiran Awal tentang Konsep Dasar Manajemen Aset Fasilitas”. Jurnal Manajemen Aset Infrastruktur \& Fasilitas, Vol. 2, Sup.1, Juni 2018, Hal.:1-14.

Sohoni, A.V., Thomas. M., \& Rao, K.V.K. (2017). "Mode shift behavior of commuters due to the introduction of new rail transit mode". Transportation Research Procedia 25, World Conference on Transport Research, Shanghai, 10-15 July 2016, pp. 2603-2618.

Suprayitno, H., Irlambang, D., Pramono, Y.A. \& Wibowo, A.G. (2006). "Karakteristik Penumpang dan Perjalanan Pada KA Penumpang Ekonomi di Wilayah Gerbangkertasusila". Jurnal Teknobisnis, Vol. 2, No. 1, Hal. : 41-48.

Suprayitno, H. \& Soemitro, R.A.A. (2018). "Preliminary Reflection on Basic Principle of Infrastructure Asset Management”. Jurnal Manajemen Aset Infrastruktur \& Fasilitas, Vol. 2, No. 1, Maret 2018, Hal.: $1-10$.

Suprayitno, H., Upa, V.A. (2017). "Mamminasata BRT User Trip Characteristics for the Design of Demand Modelling Method for a New BRT Line". IPTEK, The Journal for Technology and Science, Vol. 27, No. 3, pp. 47-52.

Suprayitno. H \& Ryansyah.M. (2018). "Karakteristik Pelaku dan Perilaku Perjalanan Penumpang Bus Trans Koetaradja," Journal Aplikasi Teknik Sipil, Vol. 16, No. 2, Hal. : 55-62.

Susanti, A., Soemitro, R.A.A. \& Suprayitno, H. (2017). "Identifikasi Awal Jalur KA Untuk Perjalanan Orang di Kota Surabaya". E-Journal Rekayasa Teknik Sipil (REKATS) UNESA, Vol. 1, No.1, Hal. : 446-451.

Upa, V.A,. Suprayitno, H. \& Ryansyah, M. (2018). "Perbandingan dan Sintesis Karakteristik Perilaku Perjalanan Pengguna Bis Trans Mamminasata dan Bis Trans Koetaradja". Jurnal Manajemen Aset Infrastruktur \& Fasilitas, Vol. 2, No. 2, Hal.: 69-82, 2018.

Wener, R.E. \& Evans, G.W. (2011). "Comparing stress of car and train commuters". Transportation Research Part F, 14, pp. 111-116.

Yosritzal., Adji, B.M., , Dissanayake, D. (2017). "Indonesian experience on travel time use on-board of commuter rail services". Transportation Research Procedia, 25, pp. 2705 2716. 
(e)ISSN 2615-1847 (p)ISSN 2615-1839 Jurnal Manajemen Aset Infrastruktur \& Fasilitas - Vol. 4, No. 3, Juli 2020 